\title{
Tren cakupan Inisiasi Menyusu Dini dan ASI Ekslusif di wilayah kerja Puskesmas Parongil, Kabupaten Dairi, Sumatera Utara. Analisis Data Sekunder Tahun 2017-2020
}

\author{
Haripin Togap Sinaga ${ }^{1}$, Marni Siregar ${ }^{2}$ \\ Dosen Jurusan Gizi Lubuk Pakam, Poltekkes Kemenkes Medan, Indonesia ${ }^{l}$ \\ Dosen Prodi Kebidanan Tarutung, Poltekkes Kemenkes Medan, Indonesia ${ }^{2}$ \\ Email :'haripinsinaga@yahoo.com, ${ }^{2}$ marnisiregar@gmail.com
}

\begin{abstract}
Background. Pandemi of Covid-19 has claimed millions of human lives and affected all aspects of human life including the implementation of early initiation of breastfeeding $(E B F)$ and exclusive breastfeeding $(E B F)$ due to prolonged lockdown. Around two-third of infant death happened in neonatal age as the results of low practices the early initiation of breastfeeding and not exclusively breastfeed. Public health center has tasks to run health community program to reach the coverage of 50\% EIBF and EBF. This study aimed to analyze the trend of prevalence of EIBF and EBF coverage from 2017 to 2020. Method. The study was a cross sectional study using secondary data taken from Parongil Public Health Center, Dairi District. Data on number of neonatal and babies aged 0-6 month and coverage EIBF and EBF were taken from monthly report. Prior to processing the data, validation was conducted. Data was presenting in univariate table in frequency distribution and proportion. Trends of EIBF and EBF coverage was presented in line graphic. Results. The trend of prevalence of EIBF had been increasing from year 2017 to 2020 that was from $77.4 \%$ to $81.6 \%$ while EBF tended to decreasing from $45 \%$ to 40.0\%. Pandemic Covid-19 might not have affected the covarage of EIBF and EBF. Factors of low education level, worked as farmers, low income, low husband support and no breastfeeding counselors were the main causes of low gaining of EBF.
\end{abstract}

Key words: Early initiation breastfeeding, Exclusive breastfeeding, Public Health Center, Pandemic Covid-19

\begin{abstract}
ABSTRAK
Pandemi Covid-19 telah merenggut jutaan nyawa manusia dikhawatirkan mempengaruhi seluruh aspek kehidupan manusia termasuk pelaksanaan IMD dan pemberian ASI Ekslusif ASI akibat lockdown yang berkepanjangan ${ }^{1}$.

Sekitar dua pertiga kematian bayi terjadi pada usia neonatal yang penyebabnya sangat berhubungan dengan tindakan inisiasi menyusu dini (IMD) dan pemberian ASI eksklusif. Puskesmas mempunyai tugas dalam melayani kesehatan masyarakat dan mencapai target minimal 50\% cakupam IMD dan 50\% pemberian ASI eksklusif. Tujuan penelitian ini adalah menganalisa kecendrungan prevalensi IMD dan pemberian ASI eksklusif dari 2017 hingga 2020. Metode. Penelitian ini merupakan studi potong lintang menggunakan data sekunder dari Puskesmas Parongil Kabupaten Dairi. Data yang dikumpulkan berupa data demografi, jumlah bayi lahir, jumlah bayi usia 0-6 bulan rekapitulasi laporan IMD dan ASI eksklusif. Sebelum melakukan pengolahan data terlebih dahulu dilakukan validasi data. Data disajikan dalam bentuk distribusi frekuensi dan proporsi. Tren pencapain IMD dan ASI eksklusif disajikan dalam grafik garis. Hasil. Kecendrungan prevalensi IMD dari tahun 2017 hingga tahun 2020 mengalami kenaikan yaitu dari 77,4\% naik menjadi 81,6\% sedangkan pemberian ASI eksklusif cenderung menurun dari 45\% menjadi dari 40,0\%. Pandemi Covid-19 kemungkinan tidak mempengaruhi pelaksanaan IMD dan ASI Ekslusif. Penyebab masih rendahanya cakupan ASI Eksklusif adalah rendahnya tingkat pendidikan, ibu bertani, kurangnya dukungan suami dan tidak adanya pendampingan dari konselor ASI.
\end{abstract}

Kata kunci: Inisiasi menyusu dini, ASI ekslusif, Puskesmas, Pandemi Covid-19. 


\section{Vol. 16 No.2 Mei - Agustus 2021}

\section{PENDAHULUAN}

Pandemi Covid-19 telah merenggut jutaan nyawa manusia dikhawatirkan mempengaruhi seluruh aspek kehidupan manusia ${ }^{2}$ termasuk pelaksanaan IMD dan pemberian ASI Ekslusif ASI akibat lockdown yang berkepanjangan ${ }^{1}$.

Sekitar dua pertiga kematian bayi usia 0-12 bulan terjadi pada saat bayi masih usia neonatal yang penyebabnya sangat berhubungan dengan tindakan inisiasi menyusu dini (IMD) dan pemberian ASI eksklusif ${ }^{3}$. Smith et al., dalam sebuah studi metaanalysis menyimpulkan bahwa jika bayi yang baru lahir mendapat ASI setelah 24 jam, maka 85\% kemungkinannya akan mengalami kematian pada usia neonatal ${ }^{4}$.

Hasil survey demografi pada 46 negara berpengahasilan rendah dan menengah menemukan hanya $42 \%$ bayi mendapat IMD pada saat satu jam pertama kelahiran ${ }^{5}$, artinya $58 \%$ bayi beresiko mengalami kematian pada usia neonatal. Menurut data WHO, secara global pada saat ini jumlah kasus positif Covid-19 adalah 97.831.595, jumlah kematian mencapai 2.120 .877 dengan case fatality rate $2,16 \%$. Sedangkan di Indonesia case fatality rate sebesar 3,47\% dimana kasus 999.256 dan kematian sebesar 28.132. Ibu yang sedang hamil dan janin menjadi populasi yang tergolong berisiko tinggi selama wabah pandemi Covid-196.

Musibah pandemi virus Corona-19 (Covid-19) telah berdampak pada pelayanan kesehatan ibu dan anak. Tingginya angka kecemasan dan ketatnya pelaksanaan protokol kesehatan membuat ibu hamil menjadi cemas melahirkan secara normal, terbukti dari hasil studi systematic review yang dilakukan oleh de Sousa, et.al., menemukan $65 \%$ ibu melahirkan dengan tindakan Caesar dan $2 \%$ diantaranya mengalami positif Covid-19, dan selebihnya melahirkan secara normal ${ }^{7}$.

Efek dari Covid-19 terhadap pelayanan kesehatan ibu terutama terhadap penerapan IMD di fasilitas kesehatan dan pemberian ASI Eksklusif sudah dipreksi oleh Hallen et.,al seperti yang ditulis pada korespondes Lancet ${ }^{8}$

Di Indonesia penelitian tentang pengaruh covid-19 terhadap tindakan persalinan dan pemberian ASI eksklusif belum banyak dilaporkan. Hasil penelitian Suryaman, dkk (2020) menemukan bahwa 59,5\% ibu menyusui memiliki kecemasan dalam memberikan ASI Eksklusif, dimana peran pengetahuan berhubungan dengan tingkat kecemasan ${ }^{9}$.

Laporan Riskesdas 2018 mendapatkan prevalensi IMD di Indonesia 58,2\% dan ASI eksklusif 37,3\% ${ }^{10}$. Sedangkan pada hasil PSG 2016 di Sumatera Utara
$30 \%$ bayi baru lahir mendapat IMD dan 12,4\% mendapat ASI Eksklusif. Sedangkan di Kabupaten Dairi hanya $13,6 \%$ bayi baru lahir mendapat IMD dan $6,2 \%$ bayi $0-6$ bulan mendapat ASI Eksklusif ${ }^{11}$

Angka pencapaian diatas masih sangat rendah jika dibandingkan dengan target Pemerintah pada tahun 2019 yaitu 50\% untuk masing-masing cakupan IMD dan ASI Eksklusif ${ }^{12}$. Pemerintah juga telah menerbitkan Kepmenkes nomor 450/2004 ${ }^{13}$ dan Peraturan Pemerintah nomor 33/2012 14 tentang peningkatan pemberian ASI Eksklusif . Program lainnya menempatkan bidan di desa dan melaksanakan program kampanye ASI ${ }^{15}$, pelatihan tentang pola pemberian makanan bayi dan anak (PMBA) bagi masyarakat desa khususnya ibu hamil dapat meningkatkan pola pemberian makanan bayi tidak hanya pada saat IMD, 0-6 bulan tapi saat usia 624 bulan 16 .

Puskesmas merupakan ujung tombak sebagai fasilitas pelayan kesehatan masyarakat yang menyelenggarakan upaya kesehatan perseorangan dan kelompok dengan mengutamakan upaya promotif dan preventif termasuk meningkatkan cakupan IMD dan ASI Eksklusif ${ }^{17}$. Puskesmas Parongil adalah salah satu Puskesmas di Kabupaten Dairi yang memberikan sumbangan terhadap pencapaian cakupanIMD dan ASI eksklusif di Kabupaten Dairi. Sejak tahun 2017, Puskesmas Parongil berupaya melakukan program peningkatan IMD dan ASI Eksklusif dengan mewajibkan ibu hamil melahirkan di klinik Puskesmas agar memudahkan pengawasan pelaksanaan IMD. Kebijakan tersebut juga berlaku hingga masa pandemi Covid-19.

Menurut perkiraan bahwa secara global praktek IMD dan ASI Eksklusif terutama di negara yang tinggi kasus Covid-19 akan mengalami penurunan akibat menurunnya aktifitas ekonomi, hubungan sosial dan pelayanan kesehatan ${ }^{6}$.

Publikasi data indikator surveilans gizi Puskesmas sebagai bahan analisis data sekunder masih jarang dilakukan. Beberapa faktor penyebabnya yaitu kemungkinan Puskesmas meragukan tingkat akurasi data dan tidak bersedia di publikasi. Namun bentuk penelitian analisis data sekunder sangat penting sebagai bahan untuk merencanakan program dan perbaikan kualitas data.

Studi ini bertujuan untuk menilai kecendrungan pelaksanaan IMD dan pemberian ASI eksklusif dari tahun 2017 hingga 2020. Data yang digunakan adalah data sekunder dari Puskesmas Parongil. Rumusan masalah bagaimana kecendrungan pemberian IMD dan ASI Eksklusif di Puskesmas Parongil dari tahun 
2017 hingga di masa Pandemi Covid-19 tahun 2020 ?.

\section{METODE}

Jenis, lokasi dan waktu penelitian

Jenis penelitian adalah cross sectional study . Lokasi penelitian adalah diwilayah kerja Puskesmas Parongil, Kabupaten Dairi Provinsi Sumatera Utara yang dilaksanakan pada bulan Januari-Maret 2021.

Populasi dan sampel

Populasi dalam penelitian ini adalah ibu yang baru melahirkan dan ibu menyusui yang mempunyai bayi umur 0-6 bulan, yang melahirkan di ruang bersalin Puskesmas Parongil pada tahun 2017, 2018, 2019 dan tahun 2020. Sedangkan sampel adalah ibu menyusui yang tercatat dalam pencatatan laporan IMD dan ASI ekskusif Puskesmas. Kriteria inklusi adalah ibu-ibu berumur 19-45 tahun yang melahirkan di Puskesmas dan ditolong oleh bidan Puskesmas.

\section{Jenis data dan sumber data}

Jenis data penelitian adalah data sekunder yang diperoleh dari petugas gizi Puskesmas meliputi data demografi seperti jumlah penduduk, jumlah desa, luas wilayah, jumlah balita, jumlah bayi baru lahir, jumlah ibu melahirkan, cakupan IMD dan cakupan ASI Eksklusif dari tahun 2017 hingga tahun 2021.

Proses pengumpulan data diawadi dengan mengajukan kepada kepala Puskesmas Parongil, Setelah mendapat persetujuan kemudia tim melakukan komunikasi dengan pengelola program gizi dan petugas KIA Puskesmas Parongil. Peneliti mempelajari data rekapitulasi cakupan IMD dan ASI eksklusif selama empat tahun. Instrumen pengumpulan data adalah kwesioner dan form laporan IMD dan ASI eksklusif.

\section{Pengolahan data}

Sebelum melakukan pengolahan data, peneliti terlebih dahulu melakukan editing data. Apabila ditemukan kejanggalan peneliti melakukan konfirmasi kepada petuga pengolah data puskesmas. Kegiatan ini dilakukan untuk memastikan sistem pencatatan dan pelaporan cakupan IMD dan ASI Eksklusif adalah sama dari sejak tahun 2017 hingga 2020.

Pengolahan dan Analisa data. Pengolahan data dilakukan dengan menggunakan program STATCAL dan analisa data menggunakan univariate dimana data disajikan dalam tabel distribusi frekuensi dan proporsi. Kemudian analisa kecendrungan menggunakan grafik garis.

\section{HASIL}

\section{Gambaran lokasi penelitian}

Puskesmas Parongil terletak di Kecamatan Silima Punggapungga dengan jarak ke Ibukota Kabupaten Dairi yaitu kota Sidikalang sekitar $27 \mathrm{~km}$ dengan luas wilayah 25,81 $\mathrm{km}^{2}$. Jarak dari ibukota Provinsi Sumatera Utara sekitar $200 \mathrm{~km}$. Secara astronomi terbentang antara $\left(80^{\circ} 00-95^{\circ} 30\right)$ Bujur Timur (BT) dan $\left(25^{\circ} 00-36^{\circ} 00\right)$ Lintang Utara (LU) dan terletak diatas permukaan Laut (570-750) meter, dengan batas wilayah : Sebelah Utara, berbatasan dengan kecamatan Siempat Nempu Hilir, sebelah Timur berbatasan dengan kecamatan Lae Parira, sebelah Selatan berbatasan dengan Propinsi Nanggroe Aceh Darussalam dan Kabupaten Pakpak Barat dan di sebelah Barat berbatasan dengan Kabupaten Aceh Selatan.

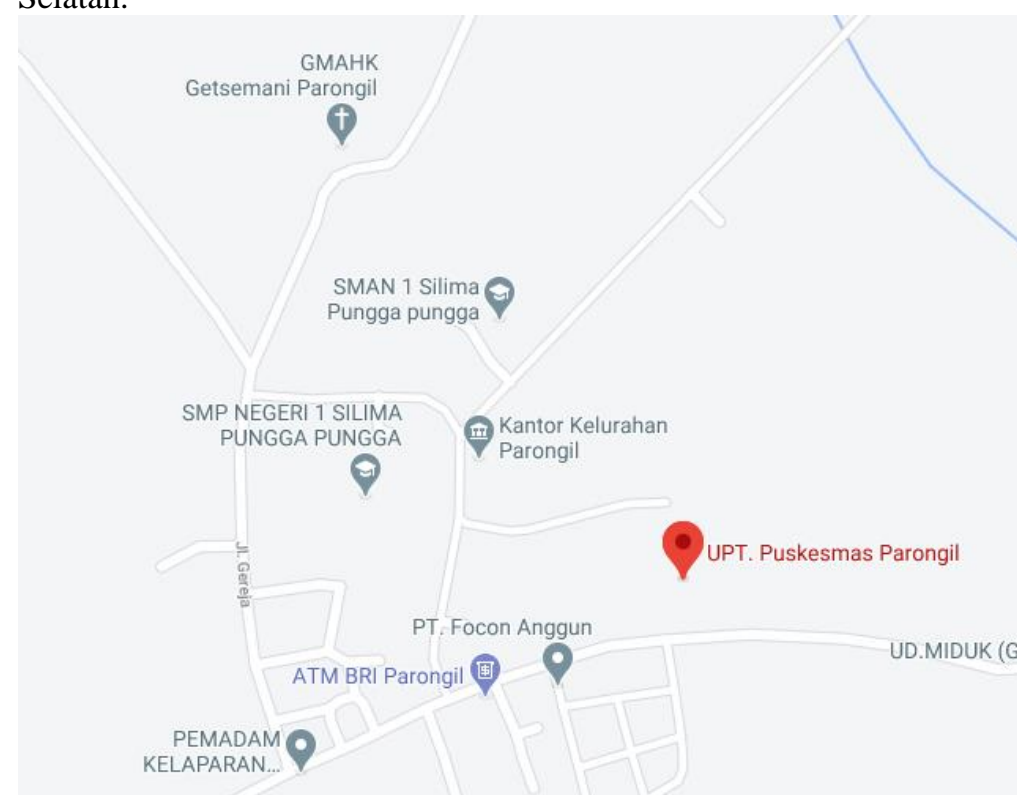

https://www.google.co.id/maps/place/UPT.+Puskesm as+Parongil

\section{Demografi}

Jumlah penduduk di kecamatan Parongil sebanyak 6376 jiwa dengan berbagai etnis. Mayoritas adalah etnis Pak-Pak dan Batak Toba. Suku lain adalah Karo, Simalungun, Jawa, Mandailing dan etnis Nias menduduki proporsi terkecil.

Mata pencaharian masyarakat mayoritas bertani kopi, padi, jagung dan beberapa jenis holtikultura termasuk durian. Kecamatan Parongil terdiri dari satu kelurahan dan lima desa dengan jumlah penduduk dan luas area seperti tabel berikut. 
Vol. 16 No.2 Mei - Agustus 2021

Tabel 1. Jumlah penduduk, luas area menurut desa di Kecamatan Parongil

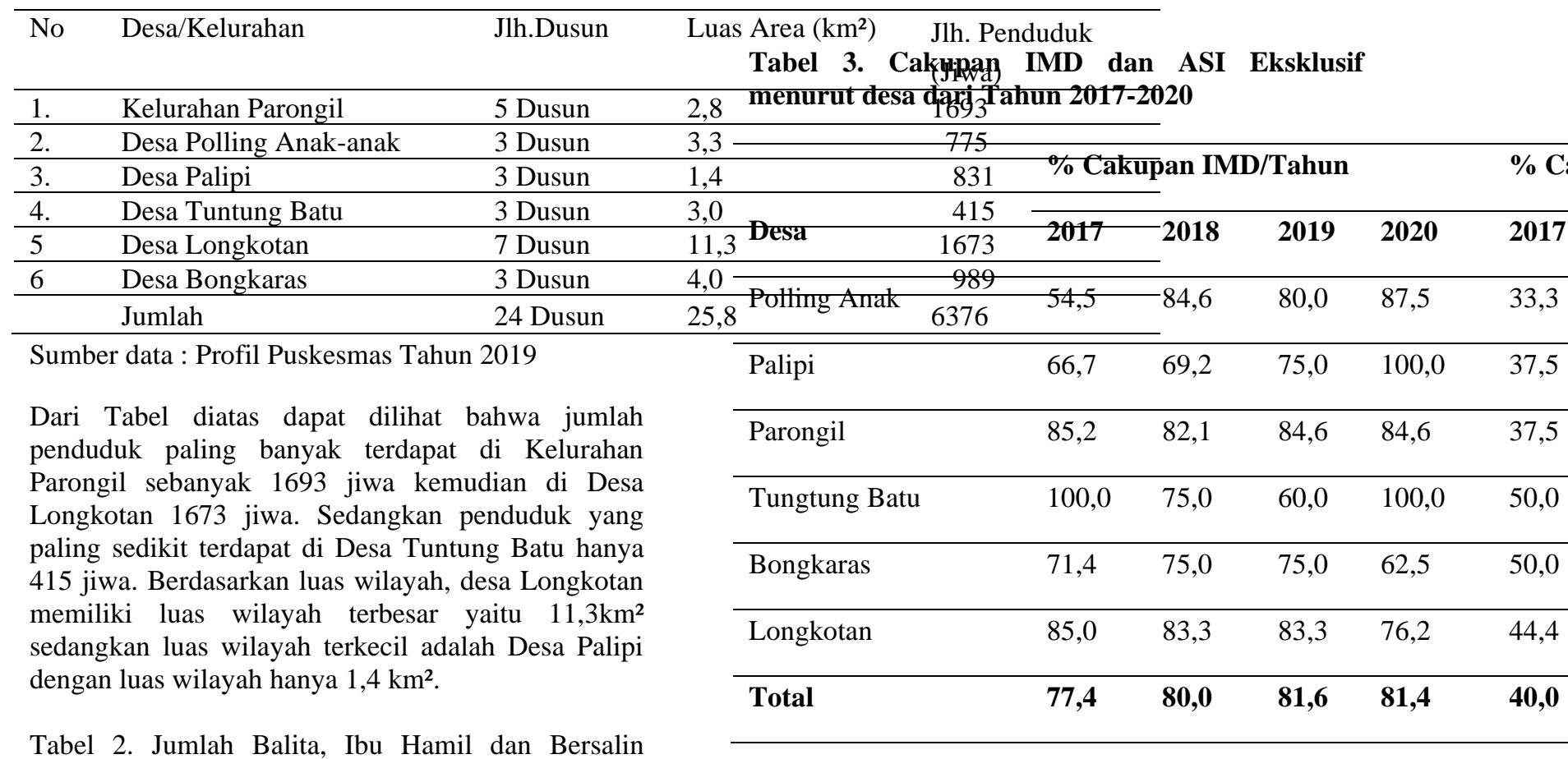
menurut Desa

\begin{tabular}{llrl}
\hline \multirow{2}{*}{ No } & Desa/Kelurahan & \multicolumn{2}{c}{} \\
\cline { 3 - 4 } & & Bayi & Batita \\
\hline 1. & Kelurahan Parongil & 18 & 88 \\
\hline 2. & Desa Polling Anak-anak & 9 & 28 \\
\hline 3. & Desa Palipi & 13 & 39 \\
\hline 4. & Desa Tuntung Batu & 6 & 16 \\
\hline 5 & Desa Longkotan & 23 & 75 \\
\hline 6 & Desa Bongkaras & 9 & 33 \\
\hline & Jumlah & 78 & 279 \\
\hline
\end{tabular}

Tabel 3 menumjukkan bahwa pada tahun 2017 seban Keglorgenokaysiabaru lahir dan 45 bayi usia $0-6$ buldalildari 84 bByimilbih dBriltinga pePersipat $(77,4 \%)$ bayilba lahir mendapat IMD. Persentese tertinggi di Desa 6hungtung \$atu, 100\% dan teregdah di Desa Pollings Anak-Anqk, 54,5\%. \$edangkamocakupan ASI Eksklqgif hanya $240,0 \%$. Dari enam degsa, dua desa

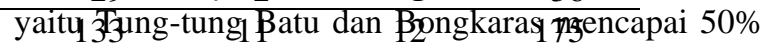
dan sempat desa fain <50,0\% $\quad 84$ Kemugdian pada tahun 20185 mayorifass (80\%) bayi baru lahir mendapat IMD. Cakupan tertinggi di desa

Tabel 2 menggambarkan distribusi jumlah bayi, batita, balita, ibu hamil, ibu bersalin dan pasangan usia subur di wilayah kerja Puskesmas Parongil tahun 2019. Total jumlah balita sebanyak 856 atau $13,4 \%$ dari jumlah penduduk (3676 jiwa). Proporsi ini $(13,4 \%)$ tergolong besar dibanding proporsi balita di tempat lain sekitar 9-11\%. Jumlah balita dan PUS terbanyak terdapat di kelurahan Parongil, 195 dan Desa Longkotan 175. Semua kategori kelompok usia paling sedikit di Desa Tungtung Batu.
Polling Anak-Anak, 84,6\% dan terendah di desa Palipi, 69,2\%. Sedangkan rata-rata cakupan ASI Eksklusif terendah di desa Bongkaras, 33,3\% dan tertinggi di desa Tungtung Batu, 66,7\%. Jika dibandingkan dengan tahun 2017, cakupan IMD dan ASI Eksklusif pada tahun 2018 mengalami kenaikan sekitar 3-5\%, IMD dari 77,4\% menjadi $80,0 \%$ dan ASI ekslusif dari 40,0\% naik menjadi 44,9\%.

Pada Tahun 2019 sebanyak 81,6\% ibu memberikan IMD dan $45,1 \%$ bayi usia $0-6$ bulan mendapat ASI Eksklusif. Cakupan IMD tertinggi di desa Longkotan, 88,5\% dan terendah di desa Tuntung Batu, 60,0\%, sedangkan cakupan ASI eksklusif masih tetap dibawah 50\%. Jika bandingkan dengan angka tahun 
2018, cakupan kedua indikator juga mengalami kenaikan sangat kecil yaitu1,6\% untuk IMD dan 0,2\% untuk ASI Eksklusif.

Pada tahun 2020 dimana terjadi wabah pandemi Covid-19, dari 86 bayi baru lahir, $81,4 \%$ mendapat IMD dan dari 57 bayi usia 0-6 bulan, 40.3\% mendapat ASI ekskulisf. Pencapaian angka IMD tidak berubah dibanding tahun 2019 tetapi cakupan ASI Eksklusif mengalami penurunan sekitar 5,0\%. Cakupan IMD tertinggi di desa Palipi dan Tungtung Batu, masing-masing 100\% sedangkan cakupan ASI Eksklusif terendah di desa Bongkaras 22,2\%. mengalami perubahan, kemudian pada tahun 2020 turun menjadi $40 \%$.

Sedangkan Prevalensi IMD cenderung naik dimulai dari angka 77,4\% pada tahun 2017 kemudian tahun 2018 grafiknya naik menuju angka 80,0\%, tahun 2019 naik lagi ke angka 81,6\%, tetapi pada tahun 2020 turun $0,2 \%$ atau mengalami stagnan di angka $81,4 \%$.

Eksklusif Tahun 2017-2020

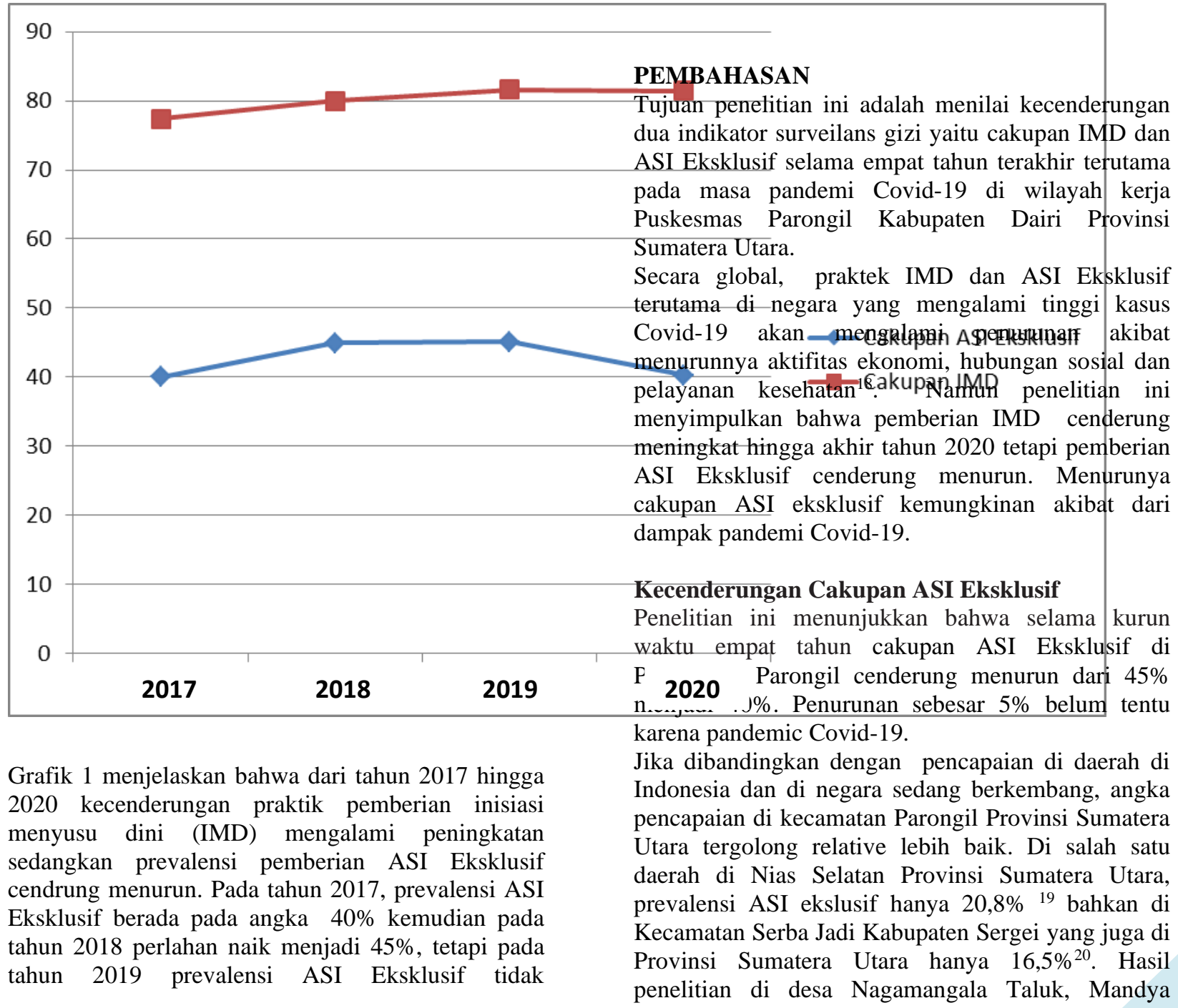




\section{Vol. 16 No.2 Mei - Agustus 2021}

District, 36\% ibu memberikan ASI Eksklusif secara penuh selama 6 bulan $^{21}$.

Sebelum tahun 2020 atau sebelum terjadi pandemi Covid-19, prevalensi ASI Eksklusif di beberapa wilayah di Sumatera Utara tergolong rendah. Hasil penelitian di kecamatan Sunggal Kota Medan tahun 2019 menemukan cakupan ASI ekslusif, sekitar 47\% 22

Jika dikaitkan dengan situasi saat ini, penurunan cakupan ASI Eksklusif kemungkinan akibat terjadinya wabah pandemi Covid-19. Pandemi Covid-19 telah mempengaruhi pelayan kesehatan memunculkan rasa khawatir baik ibu menyusui. Penelitian di Inggris menemukan bahwa akibat lockdown menyebabkan 50\% ibu tidak melanjutkan pemberian ASI hingga 6 bulan pertama ${ }^{1}$. Keadaan yang sama juga terjadi di Indonesia, dimana dalam penelitian Suryaman, dkk (2020) menemukan bahwa $59,5 \%$ ibu menyusui memiliki kecemasan dalam memberikan ASI Eksklusif ${ }^{9}$.

\section{Kecenderungan Cakupan Inisasi Menyusu Dini (IMD)}

Kecenderungan pemberian IMD di Parongil dari tahun 2017 hingga 2020 cenderung meningkat dan angka rata-rata cakupan IMD mencapai $81,6 \%$. Jika melihat data selama empat tahun hingga akhir tahun 2020, Pandemi Covid-19 tidak mempengaruhi pelaksanaan pemberian IMD di wilayah kerja Puskesmas Parongil.

Pencapaian 81,6 \% IMD di Parongil telah mencapai target nasional bahkan lebih tinggi dibanding dengan pencapaian di beberapa daerah di Indonesia seperti di Tabanan, Bali $66,7 \%^{23}$, Padang Pariaman, Padang $53,5 \%{ }^{24}$ dan di Kabupaten Bantul, Jogyakarta 63,5\% ${ }^{25}$ bahkan hasil Riskesdas 2018 melaporkan hanya $58,2 \%$ bayi baru lahir mendapat $\mathrm{IMD}^{26}$. Namun membandingkan angka-angka perlu dipertimbangkan metode survey dan pencatatan IMD di masing-masing wilayah dan level penelitian.

Kesenjangan capaian IMD dan ASI ekslusif memunculkan pertanyaan, kenapa tingginya cakupan IMD tidak diikuti dengan tingginya prevalensi ASI Ekslusif?

Penyebabnya kemungkinan beberapa faktor. Untuk mencatat data cakupan IMD jauh lebih mudah dibanding ASI eksklusif. Data IMD dapat diperoleh paling lama 24 jam setelah ibu melahirkan bayi, sedangkan ASI eksklusif memerlukan pemantauan hingga bayi berusia 6 bulan.
Kemudian faktor kebijakan lokal yang mewajibkan ibu melahirkan di fasilitas kesehatan dan di tolong bidan. Sedangkan untuk meningkatkan kesadaran ibu memberikan ASI Ekslusif memerlukan waktu yang panjang. Hasil penelitian membuktikan, walaupun pemerintah sudah mengeluarkan kebijakan yaitu Kepmekes 450/2004 ${ }^{27}$ dan PP nomor 33/2012 ${ }^{14}$. Namun kedua peraturan tersebut belum maksimal diterapkan ${ }^{28}$.

Beberapa hasil penelitian tentang IMD menyajikan lebih detail yaitu pemberian IMD <1 jam, 1-12 jam dan diatas 12 jam. Perbedaan masa waktu pemberian IMD sangat penting karena penelitian menyimpulkan bahwa bayi yang mendapat IMD >1 jam, 1,66 kali lebih besar untuk tidak mendapat ASI secara eksklusif ${ }^{29},{ }^{30}$.

Upaya peningkatan cakupan IMD dan ASI eksklusif di masa pandemi Covid-19

Penelitian mengisyarakatkan bahwa Puskesmas harus bekerja lebih keras untuk meningkatkan capaian IND dan ASI Eksklusif terutama pada masa pandemi Covid. Beberapa Negara telah menyusun strategi agar pandemic Covid-19 tidak mempengaruhi ibu dan keluarga dalam memberikan ASI kepada bayi dan panduan pemberian ASI Ekslusif terutama bagi ibu yang menderita positif Covid- $19^{31}$.

Yotebieng., et all menyarankan untuk melakukan sepuluh langkah keberhasilan pemberian SI Eksklusif pada Rumah Sakit Sayang Ibu ${ }^{32}$.

Indonesia telah megeluarkan peraturan tentang pemberian IMD dan ASI Eksklusif ${ }^{27}$. Beberapa daerah juga membuat kebijakan lokal. Dinas Kesehatan Kota Pontianak mengeluarkan peraturan agar seluruh tenaga kesehatan yang terlibat dalam pelayanan persalinan seperti bidan, perawat, dokter dan juga tokoh masyarakat mendapat informasi tentang pentingnya pelaksanaan IMD dan ASI Eksklusif ${ }^{33}$.

Hasil penelitian Rana, et.al., menemukan bahwa rendahnya capaian ASI Eksklusif erat kaitannya dengan pengetahuan dan ketrampilan pemberian $\mathrm{ASI}^{34}$. Cut Sriyanti, dkk menyarankan perlunya memaksimalkan peran bidan desa adalah melakukan pendampingan ${ }^{35}$. 


\section{Kesimpulan}

Pencapaian program IMD cenderung meningkat tetapi pemberian ASI Eksklusif cenderung menurun. Wabah Pandemi Covid-19 yang terjadi pada tahun 2020 kemungkinan tidak mempengaruhi pelaksanaan IMD dan ASI Eksklusif di wilayah kerja Puskesmas Parongil. Rendahnya capaian ASI eksklusif kemungkinan akibat faktor pendidikan rendah, pekerjaan petani, kurangnya dukungan suami dan tidak adanya pendampingan dari konselor ASI.

\section{Ucapan terimakasih}

Penulis menyampaikan terimakasih kepada dr. Rudy Purba, MKM selaku Kepala Puskesmas Parongil dan Tenaga Gizi Puskesmas ibu Dusi Karonita Sihite, STr.Gz atas kesediannya memberikan informasi dan data cakupan program gizi Puskesmas. Terimakasih juga kepada beberapa bidan desa yang tidak dapat kami sebutkan satu per satu atas konfirmasi tentang proses pencatatan IMD dan ASI Eksklusif serta rekapitulasi laporan.

\section{DAFTAR PUSTAKA}

1. Brown ANS. Experiences of breastfeeding during COVID-19: Lessons for future practical and emotional support - PubMed. Maternal and Child Nutrition. https://pubmed.ncbi.nlm.nih.gov/32969184/. Published 2020. Accessed January 4, 2021.

2. Kickbusch I, Leung GM, Bhutta ZA, Matsoso MP, Ihekweazu C, Abbasi K. Covid-19: How a virus is turning the world upside down. BMJ. 2020;369(April):10-12. doi:10.1136/bmj.m1336

3. Irawan J. Hubungan Inisiasi Menyusu Dini ( IMD ) dan pemberian Air Susu Ibu ( ASI ) Eksklusif DI RSUD Wangaya. Skala Husada. 2018.

4. Smith ER, Hurt L, Chowdhury R, Sinha B, Fawzi W, Edmond KM. Delayed breastfeeding initiation and infant survival: A systematic review and meta-analysis. PLoS One. 2017;12(7):1-16. doi:10.1371/journal.pone.0180722

5. Rukmana E, Briawan D, Ekayanti I. Faktor Risiko Stunting Pada Anak Usia 6-24 Bulan Di Kota Bogor. Media Kesehat Masy Indones Univ Hasanuddin. 2016;12(3):192-199.

6. WHO. Covid-19 current situation. 2021.
7. Francisco Á, Sousa L De, Emilia H, Watanabe E, Andrade D De, Ana F. E ff ects of COVID-19 Infection during Pregnancy and Neonatal Prognosis: What Is the Evidence?

8. Haryanti F, Mada UG, Lusmilasari L, Mada UG. Hubungan Inisiasi Menyusui Dini (Imd) Dengan Pemberian Asi Eksklusif Di Kota Manado. Kesmas. 2017;6(3).

9. Suryaman R, Girsang E. HUBUNGAN PENGETAHUAN DENGAN KECEMASAN IBU DALAM PEMBERIAN ASI PADA BAYI DIMASA PANDEMI COVID 19 aktifitas yang bagi ibu, yaitu ibu menyusui . Menyusui merupakan proses memberikan makanan pada bayi dengan menggunakan air susu ibu langsung dari payudara ib. :1-7.

10. Kemenkes RI. HASIL UTAMA RISKESDAS 2018 Kesehatan. 2018:20-21. http://www.depkes.go.id/resources/download /info-terkini/materi_rakorpop_2018/Hasil Riskesdas 2018.pdf.

11. Dinas Kesehatan Provinsi Sumatera Utara. Profil Kesehatan Provinsi Sumatera Utara tahun 2017 Indonesia. Profil Kesehat Provinsi Sumatera Utara tahun 2017 Indones. 2017:1-50. doi:10.1017/CBO9781107415324.004

12. Hartono AS, Zulfianto NA, Rachmat M. Survailans-Gizi. 2017:1-166.

13. Kepmenkes No. 450 Th. 2004 Tentang Pemberian ASI.pdf.

14. Government Regulation of Republic of Indonesia, No.33 2012. Peraturan Pemerintah Republik Indonesia Tentang Pemberian Air Susu Ibu Eksklusif Dengan Rahmat Tuhan Yang Maha Esa Presiden Republik Indonesia , Government Regulation of the Republic of Indonesia Number 33 Year 2012 on the Exclusive Breastfeeding By the G. 2012;(33).

15. Sari YD, Vidyarini TN, Indrayani II, et al. Persepsi ibu menyusui mengenai kampanye asi eksklusif di puskemas jagir surabaya. Persepsi Ibu Menyusui Mengenai Kampanye Asi Eksklus Di Puskemas Jagir Surabaya. 2014;(2011):28-29. http://repository.petra.ac.id/16715/1/Publikas i1_09003_1616.pdf. 


\section{Vol. 16 No.2 Mei - Agustus 2021}

16. Kemenkes. Pedoman Konseling Pemberian Makan Bayi dan Anak (PMBA). 2019;(21):127-129.

17. Kementerian Kesehatan Republik Indonesia (Kemenkes RI). Peraturan Menteri Kesehatan RI Nomor 75 Tahun 2014 Tentang Pusat Kesehatan Masyarakat. 2014.

18. Analita A. Hubungan antara Pemberian ASI Eksklusif dengan Kejadian Diare pada Balita di Kelurahan Ampel , Kecamatan Semampir, Kota Surabaya 2017 The Relationship between Exclusive Breastfeeding and The Incidence of Diarrhea in Toddlers in The Ampel Village, Subdis. Amerta Nutr. 2019:13-17. doi:10.20473/amnt.v3.i1.2019.13-17

19. Wardati, Nur'aini, Hadi A. Faktor predisposisi ibu usia remaja terhadap pemberian ASI Eksklusif di Nias Selatan. Fakt Presdiposisi Ibu Usia Remaja Terhadap Pemberian ASI Eksklus pada Bayi di Kec Luahagundre Maniamolo Kabupaten Nias Selatan. 2019;2(2):165. doi:10.1088/17585090/abb063

20. Doloksaribu HTSIGESB. Exclusive Breastfeeding Prevalence and Feeding Patterns of Children Living at Rural Areas in Serba Jadi Sub District, Indonesia. Int J Sci Res. 2017;6(5):676-681. doi:10.21275/ART20172981

21. Khan A, Radha R. Breast Feeding and Weaning Practices of Mothers in a Rural Area- A Cross-Sectional Study. Int J Med Sci Publich Heal. 2013;2(4):857-861. doi:10.5455/ijmsph.2013.280620131

22. Ramli R. Journal la medihealtico. 2020;01(01):8-12. doi:10.37899/journallamedihealtico.v2i1.299

23. Subratha HFA, Putra IWGAE, Duarsa DP. Faktor-faktor yang Berhubungan dengan Pemberian ASI Ekslusif pada Ibu Beraktivitas dalam Rumah di Kabupaten Tabanan. Public Heal Prev Med Arch. 2016. doi:10.15562/phpma.v4i2.72

24. Fajri Utami D, Ramadani M. Analisis Faktor Internal Dan Eksternal Program Peningkatan Pemberian ASI Ekslusif Puskesmas
Pariaman, Kota Pariaman. J Kesehat Masy. 2013. doi:10.1103/PhysRevE.73.046603

25. Lutfiyati A, Haryanti F, Lusmilasari L. Hubungan Inisiasi Menyusui Dini dengan Pemberian Asi Eksklusif. J Kesehat Madani Med. 2015.

26. Kementerian Kesehatan RI. Laporan Nasional Riskesdas 2018. Lap Nas RIskesdas 2018. 2018.

27. RI KK. Kepmenkes tentang Pemberian ASI Eksklusif nomor450/2004. 2004;(1):1-14.

28. Fikawati S, Syafiq A. Study on Policy and Implementation of Exclusive and Early Initiation of Breastfeeding in Indonesia DAN INISIASI MENYUSU DINI DI INDONESIA Abstrak. 2011;(May 2017). doi:10.7454/msk.v14i1.642

29. Mumpuni R, Utami ED. Pengaruh Inisiasi menyusui Dini (IMD) dan faktor Sosial Demografi Terhadap Ketahanan Pemberian ASI Eksklusif. E-Journal Widya Kesehat dan Lingkung. 2016;1(2):116-121.

30. Sinaga HT, Siregar M. Literatur review: Faktor penyebab rendahnya cakupan inisiasi menyusu dini dan pemberian ASI eksklusif. AcTion Aceh Nutr J. 2020;5(2):164. doi:10.30867/action.v5i2.316

31. Ranganathan R, Khan AM, Chhabra P. Antenatal care, care at birth, and breastfeeding during the Coronavirus ( COVID-19 ) pandemic. 2020;32(01):2-5.

32. Yotebieng M, Labbok M, Soeters HM, et al. Ten Steps to Successful Breastfeeding programme to promote early initiation and exclusive breastfeeding in DR Congo: A cluster-randomised controlled trial. Lancet Glob Heal. 2015;3(9):e546-e555. doi:10.1016/S2214-109X(15)00012-1

33. Komariyati. Implementasi Program Inisiasi Menyusu Dini dan Asi Eksklusif. J Ilmu Adm Negara Univ Tanjungpura. 2013;2.

34. Rana MM, Islam MR, Karim MR, et al. Knowledge and practices of exclusive breastfeeding among mothers in rural areas of Rajshahi district in Bangladesh: A community clinic based study. PLoS One. 
2020;15(5):1-11.

doi:10.1371/journal.pone.0232027

35. Sriyanti C, Siregar N, Mudatsir M, Gani A.
Effectiveness of students mentoring in exclusive breastfeeding in the districts Aceh Besar and West Aceh. AcTion Aceh Nutr J. 2019;4(2):123. doi:10.30867/action.v4i2.179 